Gut, 1984, 25, 125-128

\title{
Effects of chronic oral cimetidine on apparent liver blood flow and hepatic microsomal enzyme activity in
} man

\author{
T K DANESHMEND, M D ENE, GLYNIS PARKER, AND C J C ROBERTS \\ From the University Department of Medicine, Bristol Royal Infirmary, Bristol, Avon
}

SUMmaRY Cimetidine $200 \mathrm{mg}$ three times daily and $400 \mathrm{mg}$ at night was given to 10 subjects for four weeks. Apparent liver blood flow was measured by indocyanine green clearance and microsomal enzyme activity by antipyrine clearance, before and after cimetidine. There was no reduction in indocyanine green clearance but antipyrine clearance, as expected, was significantly reduced by $15 \%$ at four weeks. Chronic cimetidine treatment does not reduce apparent liver blood flow and is therefore unlikely to be of use in the treatment of portal hypertension. The cimetidine associated hepatic enzyme inhibition appears to persist with prolonged treatment. Therefore patients on chronic cimetidine remain vulnerable to certain drug interactions.

Propranolol has been proposed as a treatment for portal hypertension as it lowers portal venous pressure $^{1}$ and prevents recurrent gastrointestinal bleeding in cirrhotics. ${ }^{2}$ Though no toxic effects related to propranolol were observed in these cirrhotics, ${ }^{2}$ cimetidine was suggested as an alternative to propranolol. ${ }^{3}$ Cimetidine associated changes in indocyanine green clearance and propranolol kinetics in normal subjects have been interpreted as showing a reduction in apparent liver blood flow. ${ }^{4}$ The usefulness of these findings in cirrhotics with portal hypertension, however, has been questioned. ${ }^{5}$ Another histamine $\mathrm{H}_{2}$ receptor antagonist, ranitidine, has also been shown to reduce apparent liver blood flow in normals, ${ }^{6}$ though the technique criticised. ${ }^{7}$ In a recent study, ${ }^{8}$ cimetidine given intravenously to cirrhotics who had bled from oesophageal varices, failed to lower portal hypertension.

These studies with cimetidine and ranitidine have examined the effects on apparent liver blood flow and portal pressure after single doses, or short courses of these drugs. The findings of such acute studies may well be inapplicable to patients on chronic treatment with $\mathrm{H}_{2}$ receptor antagonists. We therefore studied the effect of a four week course of cimetidine on apparent liver blood flow. In previous

Address for correspondence: Dr T K Daneshmend, Department of Medicine, Southmead Hospital, Bristol, Avon BS10 5NB.

Received for publication 22 April 1983 studies a relationship between hepatic microsomal enzyme induction and apparent liver blood flow has been noted. ${ }^{9}{ }^{10}$ Consequently, we also examined the enzyme inhibiting effect of cimetidine to determine whether there was a relationship between enzyme inhibition and a change in apparent liver blood flow.

\section{Methods}

SUBJECTS

Six healthy men and four healthy women aged 20 to 45 years completed the study which was approved by the hospital ethical committee. All were nonsmokers, drank only moderate amounts of alcohol and were not on any medication including the oral contraceptive pill. Plasma indocyanine green kinetics and antipyrine kinetics were determined in each subject before and after a four week course of cimetidine $200 \mathrm{mg}$ three times per day and $400 \mathrm{mg}$ at night.

After an overnight fast subjects rested supine for one hour. The experimental conditions were standardised as previously described. ${ }^{11}$ Indocyanine green kinetics were then measured after a single intravenous bolus of $0.5 \mathrm{mg}$ of dye per kilogram body weight. Venous blood samples were taken from the opposite arm at three minute intervals for 21 minutes. Before an indocyanine green injection was given, a venous blood sample was collected for measurement of blood haematocrit by automated methods on a Coulter Super-S counter. Indocyanine 
green plasma concentrations were measured by a spectrophotometric method. ${ }^{12}$

After the indocyanine green kinetics had been performed, antipyrine $1200 \mathrm{mg}$ was administered as a freshly prepared solution and venous blood samples collected before and after three, six, nine, 12 and 24 hours after the dose. Plasma antipyrine was measured by a high performance liquid chromatographic method, ${ }^{13}$ modified by the use of $20 \%$ acetonitrile in $0.05 \mathrm{M}$ phosphate buffer at $\mathrm{pH}$ 6.5 as mobile phase.

Plasma clearance, volume of distribution and plasma half life of indocyanine green were calculated from $\log$ concentration time curves as previously described. ${ }^{14}$ Whole blood clearance of indocyanine green was assumed to be equivalent to apparent liver blood flow and calculated as follows:

Apparent liver blood flow

$$
=\frac{\text { Plasma clearance of ICG } \times 100}{[100-\text { haematocrit }(\%)]}
$$

Plasma antipyrine half life was calculated from least squares regression analysis of the log plasma concentration-time profile. Assuming complete absorption, negligible first pass metabolism and a one compartment model for antipyrine, ${ }^{15}$ the apparent volume of distribution of antipyrine was estimated as:

$$
\text { Apparent volume of distribution }=\frac{\text { Dose }}{\text { Cpo }}
$$

where Cpo is the back extrapolated plasma concentration at time zero. Plasma clearance of antipyrine was calculated as:

Plasma clearance

$$
=\text { apparent volume of distribution } \times \frac{0.693}{T^{\frac{1}{2}}}
$$

where $T \frac{1}{2}$ is the half life of antipyrine and $0.693 \mathrm{a}$ constant.

Statistical comparisons were made using Student's $t$ test for paired data. Significance was assumed at $\mathrm{p}<0.05$.

\section{Results}

There were no adverse effects to cimetidine, antipyrine or indocyanine green in this study. Complete data were available from all subjects for indocyanine green kinetics, but from only eight subjects for antipyrine kinetics.

The results of indocyanine green kinetics are summarised in Table 1. There was no change in the half life of indocyanine green after cimetidine. The
Table 1 Indocyanine green (ICG) kinetics before and after cimetidine $1 \mathrm{~g}$ per day for four weeks, in 10 subjects (mean $\pm S D)$

\begin{tabular}{lccl}
\hline & $\begin{array}{l}\text { Before } \\
\text { cimetidine }\end{array}$ & $\begin{array}{l}\text { After } \\
\text { cimetidine }\end{array}$ & p value* \\
\hline $\begin{array}{l}\text { ICG half life (min) } \\
\text { ICG volume of } \\
\text { distribution (litres) }\end{array}$ & $3 \cdot 70 \pm 0 \cdot 71$ & $3 \cdot 74 \pm 0 \cdot 78$ & NS \\
$\begin{array}{c}\text { ICG clearance } \\
\text { (ml/min) }\end{array}$ & $621 \cdot 8 \pm 121 \cdot 7$ & $727 \cdot 1 \pm 206 \cdot 3$ & NS \\
$\begin{array}{c}\text { Apparent liver blood } \\
\text { flow (ml/min) }\end{array}$ & $1081 \cdot 1 \pm 188.7$ & $1283.0 \pm 374 \cdot 1$ & NS \\
\hline
\end{tabular}

* Student's $t$ test for paired data.

NS = not significant.

mean volume of distribution of indocyanine green, clearance of indocyanine green and apparent liver blood flow increased by 19,17 , and $19 \%$ respectively after cimetidine, but these changes were not significant.

Antipyrine kinetics are summarised in Table 2. There was a $15 \%$ reduction in antipyrine clearance and $18 \%$ increase in antipyrine half life after cimetidine. These changes were significant. Apparent volume of distribution of antipyrine was not altered by cimetidine.

There were no correlations between changes in indocyanine green kinetics and changes in antipyrine kinetics in individual subjects.

\section{Discussion}

The absence of a significant change in indocyanine green clearance in this study clearly shows that the reductions in apparent liver blood flow previously observed $^{4}$ after single doses or short courses of cimetidine are not maintained during a full four week course of treatment. The reduction in antipyrine clearance, however, shows that the enzyme inhibiting effect of cimetidine may continue throughout treatment.

Table 2 Antipyrine kinetics before and after cimetidine $1 \mathrm{~g}$ per day for four weeks, in eight subjects (mean $\pm S D$ )

\begin{tabular}{llll}
\hline & $\begin{array}{l}\text { Before } \\
\text { cimetidine }\end{array}$ & $\begin{array}{l}\text { After } \\
\text { cimetidine }\end{array}$ & p value* \\
\hline $\begin{array}{c}\text { Antipyrine half life (h) } \\
\text { Antipyrine volume of } \\
\text { distribution (litres) }\end{array}$ & $12.2 \pm 2.0$ & $14.3 \pm 3.4$ & $<0.05$ \\
$\begin{array}{c}\text { Antipyrine clearance } \\
(\mathrm{ml} / \mathrm{min})\end{array}$ & $38.1 \pm 5.6$ & $36.0 \pm 7.5$ & $\mathrm{NS}$ \\
\hline
\end{tabular}

* Student's $t$ test for paired data.

NS $=$ not significant . 
In the context of regional blood flow, this finding is not altogether surprising. The cimetidineassociated decrease in effective renal plasma flow observed after one and seven days of treatment had returned to basal values after three weeks of cimetidine treatment. ${ }^{16}$ Another study examined the effects of cimetidine on cerebral blood flow after a single intravenous dose, and found no reduction in young or elderly subjects. ${ }^{17}$ Bolus injections of cimetidine $400 \mathrm{mg}$ were noted to produce only transient (10 minute) decreases in systemic and pulmonary arterial pressure, but no changes in cardiac output. ${ }^{18}$ Chronic oral cimetidine $400 \mathrm{mg}$ four times daily, however, produced no demonstrable cardiovascular changes. ${ }^{19}$

In the present study we did not examine the effects of a single dose or a short course of cimetidine on apparent liver blood flow. Therefore we are unable to state whether there was any reduction in apparent liver blood flow in our subjects. It is possible that there may have been some reduction in apparent liver blood flow at the start of treatment which had disappeared after four weeks of treatment. Another possible but unlikely explanation for our findings is a cimetidineassociated change in the intrinsic hepatic extraction ratio of indocyanine green such that it offset the change in hepatic blood flow and resulted in an unchanged value for indocyanine green clearance.

Acute intraportal administration of histamine receptor antagonists in normals and in patients with portal hypertension secondary to hepatosplenic schistosomiasis, suggests a role for $\mathrm{H}_{1}$ rather than $\mathrm{H}_{2}$ receptor antagonists in the pathogenesis of portal hypertension. ${ }^{20}$ In animals, administration of histamine into the hepatic artery leads to vasodilatation, while intraportal administration leads to a rise in portal vascular resistance. ${ }^{21-23}$ These responses to histamine are blocked by $\mathrm{H}_{1}$ receptor antagonists but not by $\mathrm{H}_{2}$ receptor antagonists. ${ }^{23}$ On the basis of our findings, and the failure of intravenous cimetidine to lower portal pressure in patients with cirrhosis and portal hypertension, ${ }^{8}$ we cannot support the suggested use of cimetidine as a treatment for portal hypertension. ${ }^{3}$ In man it is unlikely that other $\mathrm{H}_{2}$ receptor antagonists such as ranitidine, or currently available $\mathrm{H}_{1}$ receptor antagonists will be found useful in the treatment of portal hypertension.

In contrast with the possible transient effect of cimetidine on liver blood flow, the effect on microsomal enzyme activity appears to persist. We have previously noted a similar reduction in antipyrine clearance after a three day course of cimetidine $400 \mathrm{mg}$ four times per day. ${ }^{24}$ This reduction in hepatic microsomal enzyme activity is probably the basis for a large number of interactions between cimetidine and other drugs, ${ }^{25}$ the notable pharmacokinetic ones being with anticoagulants, ${ }^{26}$ anticonvulsants, ${ }^{27} 28$ and adrenoceptor antagonists. ${ }^{42930}$ The present study shows that compensatory mechanisms, if any, do not reduce this enzyme inhibiting effect during four weeks of chronic therapy with cimetidine. Consequently patients on chronic cimetidine treatment remain vulnerable to such drug interactions.

We thank Miss Julia Ford, Mrs Carol Truman, and Mrs Elaine Shrosbree, SRN, for their technical assistance. We also thank Smith, Kline and French Laboratories, Welwyn Garden City, for support and supplies of cimetidine.

\section{References}

1 Lebrec D, Nouel O, Corbic H, Benhamou J-P. Propranolol - a medical treatment for portal hypertension. Lancet 1980; 2: 180-2.

2 Lebrec D, Nouel O, Bernuau J, Bouygues M, Rueff B, Benhamou J-P. Propranolol in prevention of recurrent gastrointestinal bleeding in cirrhotic patients. Lancet 1981; 1: 920-1.

3 Schneider RE, Bishop $\mathrm{H}$. $\mathrm{H} 2$ receptor antagonists for portal hypertension. Lancet 1981; 2: 152.

4 Feely J, Wilkinson GR, Wood AJJ. Reduction of liver blood flow and propranolol metabolism by cimetidine. N Engl J Med 1981; 304: 692-5.

5 Lebrec D, Goldfarb G, Benhamou J-P. Reduction of liver blood flow by cimetidine. $N$ Engl J Med 1981; 305: 100 .

6 Feely J, Guy E. Ranitidine also reduces liver blood flow. Lancet 1982; 1: 169.

7 Grainger SL, Marigold JH, Keeling PWN. Ranitidine and liver blood flow. Lancet 1982; 1: 398.

8 Burroughs AK, Walt R, Dunk A et al. Effect of cimetidine on portal hypertension in cirrhotic patients. Br Med J 1982; 284: 1159-60.

9 Branch RA, Shand DG, Wilkinson GR, Nies AS. Increased clearance of antipyrine and d-propranolol after phenobarbital treatment in the monkey. J Clin Invest 1974; 53: 1101-7.

10 Ohnhaus EE, Thorgierson SS, Davies DS, Breckenridge $A$. Changes in liver blood flow during enzyme induction. Biochem Pharmacol 1971; 20: 2561-70.

11 Daneshmend TK, Jackson L, Roberts CJC. Physiological and pharmacological variability in estimated heptic blood flow in man. Br J Clin Pharmacol 1981; 11: 491-6.

12 Caesar J, Shaldon S, Chiandussi L, Guevara L, Sherlock S. The use of indocyanine green in the assessment of hepatic blood flow as a test of hepatic function. Clin Sci 1961; 21: 43-57.

13 Danhof $M$, De Groot van der Vis E, Breimer DD. 
Assay of antipyrine and its primary metabolites in plasma, saliva and urine by high performance liquid chromatography and some preliminary results in man. Pharmacology 1979; 18: 210-23.

14 Roberts CJC, Jackson L, Halliwell M, Branch RA. The relationship between liver volume, antipyrine clearance and indocyanine green clearance before and after phenobarbitone administration in man. $\mathrm{Br} J$ Clin Pharmacol 1976; 3: 907-13.

15 Andreasen PB, Vesell ES. Comparison of plasma levels of antipyrine, tolbutamide and warfarin after oral and intravenous administration. Clin Pharmacol Ther 1974; 16: 1059-65.

16 Dutt MK, Moody P, Northfield TC. Effect of cimetidine on renal function in man. $\mathrm{Br} \mathrm{J}$ Clin Pharmacol 1981; 12: 47-50.

17 Harris A, Cook PJ, Jewell DP, James IM. Cimetidine and cerebral blood flow in elderly patients. $\mathrm{Br} \mathrm{J}$ Clin Pharmacol 1981; 11: 93-4.

18 Lee PK, Lai CL, Lok ASF et al. Haemodynamic responses to intravenous cimetidine in subjects with normal lung function and in subjects with chronic airways obstruction. Br J Clin Pharmacol 1981; 11: $339-43$.

19 Saltissi S, Crowther A, Byrne C, Coltart DJ. The effects of chronic oral cimetidine therapy on the cardiovascular system in man. Br J Clin Pharmacol 1981; 11: 497-503.

20 El-Gindi MA, Nassar SH. Effect of histamine and histamine antagonists on portal blood pressure in patients with hepatosplenic schistosomiasis. $\mathrm{Br} \mathrm{J} \mathrm{Clin}$ Pharmacol 1980; 10: 157-61.
21 Richardson PDI, Withrington PG. The vasodilator actions of isoprenaline, histamine, prostaglandin E2, glucagon, and secretin on the hepatic arterial vascular bed of the dog. BrJ Pharmacol 1976; 57: 581-8.

22 Richardson PDI, Withrington PG. Liver blood flow. I. Intrinsic and nervous control of liver blood flow. Gastroenterology 1981; 81: 159-73.

23 Richardson PDI, Withrington PG. Liver blood flow. II. Effects of drugs and hormones on liver blood flow. Gastroenterology 1981; 81: 356-75.

24 Daneshmend TK, Ford J, Roberts CJC. Variability in the enzyme inhibiting effect of cimetidine in man $B r J$ Clin Pharmacol 1981; 11: 421P.

25 Bauman JH, Kimelblatt BJ. Cimetidine as an inhibitor of drug metabolism: therapeutic implications and review of literature. Drug Int Clin Pharmacol 1982; 16: $380-6$.

26 Serlin MJ, Sibeon RG, Mossman S et al. Cimetidine interaction with oral anticoagulants in man. Lancet 1979; 2: 317-9.

27 Algozzine GJ, Stewart RB, Springer PK. Decreased clearance of phenytoin with cimetidine. Ann Intern Med 1981: 95: 244-5.

28 Neuvonen PJ, Tokola R, Kaste M. Cimetidinephenytoin interaction: effect on serum phenytoin concentration and antipyrine test. Eur J Clin Pharmacol 1981; 21: 215-20.

29 Heagerty AM, Donovan MA, Castleden CM, Pohl JF, Patel $\mathrm{L}$. Influence of cimetidine on pharmacokinetics of propranolol. Br Med J 1981; 282: 1917-9.

30 Daneshmend TK, Roberts CJC. Cimetidine and bioavailability of labetalol. Lancet 1981; 1: 565 . 